\title{
Microclimate modification through shading and watering frequency treatments as efforts for ex-situ conservation of pule pandak (Rauvolfia serpentina)
}

\author{
SAMANHUDI", EDI PURWANTO, SULANDJARI, ARY SETIYANINGSIH \\ Department of Agronomy, Program of Graduates, Universitas Sebelas Maret. Jl. Ir. Sutami 36 A, Surakarta 57126, Central Java, Indonesia. \\ Tel./Fax.: +62-271-632450, 637457, `email: samanhudi@ymail.com
}

Manuscript received: 21 June 2016. Revision accepted: 22 June 2017.

\begin{abstract}
Samanhudi, Purwanto E, Sulandjari, Setiyaningsih A. 2017. Microclimate modification through shading and watering frequency treatments as efforts for ex-situ conservation of pule pandak (Rauvolfia serpentina). Asian J Agric 1: 35-39. Pule pandak (Rauvolfia serpentina Benth) is a rare medicinal plant. To meet the needs of the drug, people continue to explore nature. Thus, proper cultivation technique for $R$. serpentina is required, by giving appropriate shading level and watering frequency to the growth and yield of $R$. serpentina. This research aimed to examine the effects of shading and watering frequency on the growth and yield of $R$. serpentina. The study was conducted from February to July 2009 in BBP Mondromino, Pokoh Village, Wonogiri at 141 meters above sea level. The experimental design used in this research was a Split Plot Design, which consisted of two factors and three repetitions. The first factor (main plot) was a shading level that consisted of three levels: 55\%, 65\%, and 75\%. The second factor (subplot) was watering frequency that consisted of three levels: once every three days, once every five days and once every seven days. Data were subjected to analysis of variance, followed by post hoc test of Duncan Multiple Range Test at 5\% level. The reserpine content was analyzed descriptively. The results showed that no interaction between shading level and watering frequency was seen on all variables. The shading level caused no significant effect on growth and yield of $R$. serpentina, except the leaf area. Watering frequency caused no significant effect on growth and yield of $R$. serpentina, apart from the chlorophyll content. The results showed that plants treated with watering frequency of five-day intervals produced the highest chlorophyll content. Plants treated with shading level of $65 \%$ and watering frequency of once every five days produced the highest reserpine content.
\end{abstract}

Keywords: Pule pandak, Rauvolfia serpentina, reserpine shading, watering frequency

\section{INTRODUCTION}

Indonesia is a country that is rich in biodiversity, including medicinal plants. There are thousands of medicinal plant species that exist in various areas in Indonesia, especially in forest ecosystems. As the need for health care increases, there is a global issue of "back to nature" and strong sociocultural support in the use of traditional medicine, which makes medicinal plants more sought after. Lifestyle changes such as these, will provide greater market opportunities that can provide a positive impact on the development of traditional medicine industry and phytopharmaca.

One of the important medicinal plants is Rauvolfia serpentina Benth, also known by the local name of pule pandak. Roots of $R$. serpentina are a major part of the plant that is exploited for medical purposes, although the leaves and stems are also useful. $R$. serpentina contains about 50 kinds of alkaloids that have been isolated. Among the alkaloids is reserpine, the most important element in the roots of $R$. serpentina which acts as an anti-hypertension (Sulandjari et al. 2005).

Now, $R$. serpentina is still considered a rare medicinal plant. Exploration of nature continues to happen to meet the needs of drugs. This will probably make the plant even more scarce, thus there is a need for efforts to cultivate $R$. serpentina to produce large quantities of the crops' root extract with a high alkaloid content. Cultivation technologies that can be applied to this plant include setting the most appropriate levels of shading and watering frequency. Application of appropriate levels of shading and watering frequency will enable the plant to grow well and produce high reserpine.

The intensity of light received by the plant at a level lower than $40 \%$, inhibits plant growth since light intensity is closely related to the opening of stomata. Water availability and sunlight are also crucial for plants and be important limiting factors for plant growth. Water stress may hamper plant growth, particularly the enlargement of cells and decrease the turgor potential (Sitompul 1995 cit Herlina 1996). Drought stress causes a decrease in photosynthesis, as seen from the reduction in net assimilation rate, that could result in reduced yield components of both quality and quantity (Herlina 1996).

A secondary metabolite is a chemical rather than a nutrient, with diverse chemical structures which limit the spread of its biosynthesis process influenced by the number and activity of enzymes. Secondary metabolite biosynthesis is genetically controlled and highly influenced by the environment. Reserpine is the primary alkaloid in $R$. serpentina and is a secondary metabolite that belongs to the indole alkaloids complex. In general, water shortage and 
low light intensity could induce the formation of secondary metabolites as a defense reaction.

This study aimed to examine the influence of shading level and watering frequency on growth and yield of $R$. serpentina and to assess the interaction between the level of shading and watering frequency on growth and yield of $R$. serpentina.

\section{MATERIALS AND METHODS}

This research was conducted from February until August 2009 at the BBP Mondromino, Pokoh Village, Wonogiri with an elevation of $141 \mathrm{~m}$ above sea level. This study employed a Split Plot Design consisting of two factors and three replications. The first factor (the main plot) was the level of shading which consisted of three levels, namely: $55 \%$ shading (N1), 65\% shading (N2) and $75 \%$ shading (N3). The second factor (the sub-plot) was the frequency of the water supply consisted of three levels, i.e., watering in three-day intervals (A1), five-day intervals (A2) and seven-day intervals (A3). Materials used in this study included pule pandak (Rauvolfia serpentina Benth.), paranet, soil, water, polybags, and manure. The equipment used was a hoe, trowel, digital balance, ovens, ruler, cutter, lux meters, thermohygrometer, and a shovel.

Implementation of this research included nurseries, land preparation, planting preparation, planting, maintenance, and harvesting. The variables measured were plant height, leaf number, leaf area plant ${ }^{-1}$, chlorophyll content, root length, root diameter, specific leaf area, roots-crown ratio, the weight of simplicia, and the reserpine content.

Obtained data were subjected to analysis of variance according to the split-plot design approach. A post hoc test of Duncan's multiple range test (DMRT) at 5\% level was used to compare the treatment means. Reserpine content was analyzed descriptively.

\section{RESULTS AND DISCUSSION}

Rauvolfia serpentina is considered a medicinal plant. The main part that is used for medicinal purposes is the roots. $R$. serpentina contains no less than 50 kinds of alkaloids that have been isolated. Among the alkaloids is reserpine; the most important element in the root of $R$. serpentina which acts as antihypertensive (Sulandjari et al. 2005). The availability of water and shade at the appropriate level are both important aspects that can affect growth and yield of $R$. serpentina. The analysis of variance showed no interaction between shading level and watering frequency on all variables. The significant effect of shading treatment only occurred on the variable leaf area, whereas the significant effect of water frequency was observed only on the chlorophyll content.

\section{Plant height}

Plant height is the most frequently observed variable both as an indicator of growth as well as the parameter used to measure the environmental effect of the treatment applied (Sitompul and Guritno 1995). Analysis of variance showed no significant interaction effect of shading level and watering frequency on plant height. This means that the plant experienced no etiolation during the experiment. Presumably, the plants were tolerant to low-light intensity and that the metabolism of the plants under stress conditions was similar to that at field capacity level.

\section{Number of leaves}

The analysis of variance showed that the treatments of shading level and watering frequency caused no significant interaction effect on the number of leaves. This is probably because the number of leaves tends to be more influenced by genetic factors. We found in the present research that several plants suffered leaf loss. In addition, the number of leaves will increase with increasing plant height; however, we found no significant increase in the number of leaves in this study because the plant height of the tested plants did not increase significantly.

\section{Leaf area}

The leaf is the organ where the process of photosynthesis occurs. If leaf area increases, the photosynthesis rate will increase, and the plant growth and plant dry weight will also increase. Based on our analysis of variance, shading treatment significantly affected leaf area, whereas the watering frequency treatment caused no significant effect on leaf area.

DMRT 5\% (Table 3) test shows that 75\% shading level produced a lower leaf area as compared to other shading levels. This is, presumably, due to the low light intensity, which in turn caused inhibition of photosynthesis and resulted in a decrease of number of leaves and ultimately, a decrease of leaf area of the plant.

\section{Chlorophyll content}

Chlorophyll is the photosynthetic pigment found in plant that functions to absorb red, blue, and purple lights and reflects green light, which causes plants to get their color characteristics. Chlorophyll is found in the chloroplasts and uses the absorbed sunlight energy as the light reactions in photosynthesis (Streitweiser and Heathcock 1981). Based on the analysis of variance, we found that shading treatment had no significant effect on chlorophyll content, which may be because not the entire chlorophyll content is influenced by light. Lakitan (1993) stated that the shaded leaves contained more chlorophyll (especially chlorophyll b) per unit of leaf weight because the shaded leaves formed more grana as an adaptation strategy to absorb light more efficiently.

The present study results revealed that the frequency of watering in five-day intervals could raise the levels of chlorophyll content. Presumably, in this water shortage condition, the plants tended to produce higher amino acid. One of amino acids is nitrogen, which is the main component of chlorophyll. Differences in the water supply for three-day and five-day intervals showed significantly elevated levels of chlorophyll. However, more severe water shortage conditions may show a decrease in chlorophyll content. The accumulation of photosynthetic pigments 
because of exogenous application of salicylic acid may be due to increased photosynthesis efficiency as reflected by increasing contents of both chlorophylls a and chlorophyll b on $R$. serpentina.

The occurrence of water loss due to water stress that is not followed by the entry of water into the plant at the same speed will cause decrease in cell turgor. This caused leaves to wither and light interception into the plant decreased (Islami and Utomo 1995). It is suspected that provision of water once every seven days, causing very low light interception into the plants, which in turn caused the inhibition of photosynthesis process and hence damage to the plant tissues, including the chlorophyll.

\section{Root length}

The root is the lower part of the plant that usually grows beneath the soil surface and serves to absorb water, minerals, and materials essential for plant growth and development (Hidayat 1995; Gardner et al. 1991). Based on analysis of variance we found that shading and watering frequency treatments caused no significant effect on root length. Gardner et al. (1991) stated that water shortage that was relatively short in time but is severe, may not significantly affect crop yields; on the other hand, an extended period of water shortages that are not so severe may have a greater influence on the yield. In this research, the shortage of water, was relatively short so that root growth was not significantly affected.

\section{Root diameter}

One indicator of root growth is the root diameter increment. The analysis of variance of root diameter showed that both the treatments of shading and watering frequency had no significant effect on root diameter. This is probably because root growth is more influenced by the availability of adequate nutrients, so that the levels of shading and watering frequency had no significant effect on root diameter.

\section{Specific leaf area}

Not all light received by plants is absorbed by the leaves. The lights are partially reflected and partly transmitted by the plant leaves. Transmission of light through the leaves is determined by several factors, including leaf thickness that is expressed in specific leaf areas. Specific leaf area is the weight of leaf per unit leaf area (Guritno and Purnomo 2006). Based on analysis of variance of the specific leaf area, the treatments of shading and watering frequency had no significant effect on specific leaf area, presumably because the plants are resistant to the drought.

Based on Figure 1, the highest specific leaf area was found at $55 \%$ shading level, i.e., $52.44 \mathrm{~cm}^{2} \mathrm{~g}^{-1}$ and the lowest was at $75 \%$ shading level. According to Fosked (1994), a plant that grew in an environment of low radiation intensity will etiolate with a more dominant longitudinal growth. At dark condition, proplastids do not turn into a chloroplast but become an etioplast, so that the lower the specific leaf area is in line with the increasing shading level. Presumably, this is what makes leaves slimmer at the high shading level condition. However, according to analysis of variance, the differences in specific leaf areas due to increasing shading levels are not significant, which means the leaves had not yet shown symptoms of etiolation.

Table 1. Means of plant height at various levels of shading and watering frequency

\begin{tabular}{|c|c|c|c|c|}
\hline \multirow{2}{*}{$\begin{array}{c}\text { Level of } \\
\text { shading }(\%)\end{array}$} & \multicolumn{3}{|c|}{ Watering frequency (days) } & \multirow{2}{*}{$\begin{array}{c}\text { Means } \\
(\mathrm{cm})\end{array}$} \\
\hline & 3 & 5 & 7 & \\
\hline 55 & 29.70 & 30.03 & 32.46 & $30.73 \mathrm{a}$ \\
\hline 65 & 25.10 & 23.67 & 26.50 & $25.09 \mathrm{a}$ \\
\hline 75 & 17.63 & 23.80 & 19.73 & $20.39 \mathrm{a}$ \\
\hline Means (cm) & $24.14 \mathrm{c}$ & $25.83 \mathrm{c}$ & $26.23 \mathrm{c}$ & $(-)$ \\
\hline
\end{tabular}

Note: Means on the same column or same line followed by the same letter are not significantly different at 5\% DMRT.(-): no interaction.

Table 2. Means of leaf number at various levels of shading and watering frequency

\begin{tabular}{lcccl}
\hline Level of & \multicolumn{3}{c}{ Watering frequency (days) } & \multirow{2}{*}{ Means } \\
\cline { 2 - 4 } shading (\%) & $\mathbf{3}$ & $\mathbf{5}$ & $\mathbf{7}$ & \\
\hline 55 & 30.42 & 26.75 & 30.83 & $29.33 \mathrm{a}$ \\
65 & 24.08 & 22.75 & 25.08 & $23.97 \mathrm{a}$ \\
75 & 19.25 & 22.92 & 19.75 & $20.64 \mathrm{a}$ \\
Means & $24.58 \mathrm{c}$ & $24.14 \mathrm{c}$ & $25.22 \mathrm{c}$ & $(-)$ \\
\hline
\end{tabular}

Note: Means on the same column or same line followed by the same letter are not significantly different at 5\% DMRT. (-) : no interaction

Table 3. The effect of shading level on leaf area of Rauvolfia serpentina

\begin{tabular}{cc}
\hline Shading level $(\boldsymbol{\%})$ & Leaf area $\left(\mathbf{c m}^{2}\right)$ \\
\hline 55 & $2014.98 \mathrm{a}$ \\
65 & $1503.16 \mathrm{a}$ \\
75 & $842.64 \mathrm{~b}$ \\
\hline
\end{tabular}

Note: Means followed by the same letter are not significantly different at 5\% DMRT.

Table 4. The effect of watering frequency on chlorophyll content of Rauvolfia serpentina

\begin{tabular}{cc}
\hline Watering frequency (day) & Chlorophyll content $(\boldsymbol{\%})$ \\
\hline 3 & $33.30 \mathrm{a}$ \\
5 & $40.90 \mathrm{~b}$ \\
7 & $38.98 \mathrm{~b}$
\end{tabular}

Note: Means followed by the same letter are not significantly different at 5\% DMRT 
Table 5. Means of root length at various levels of shade and watering frequency

\begin{tabular}{lcccc}
\hline \multirow{2}{*}{$\begin{array}{c}\text { Level of } \\
\text { shading (\%) }\end{array}$} & \multicolumn{3}{c}{ Watering frequency (days) } & \multicolumn{1}{c}{\begin{tabular}{c} 
Means \\
\cline { 2 - 4 }$(\mathbf{c m})$
\end{tabular}} \\
\hline 55 & $\mathbf{3}$ & $\mathbf{5}$ & $\mathbf{7}$ & \multicolumn{1}{c}{$22.16 \mathrm{a}$} \\
65 & 26.33 & 21.33 & 18.83 & $20.89 \mathrm{a}$ \\
75 & 21.67 & 21.50 & 19.50 & $20.39 \mathrm{a}$ \\
Means $(\mathrm{cm})$ & 20.67 & 19.00 & 21.50 & $\mathrm{c}$ \\
\hline
\end{tabular}

Note: Means on the same column or same line followed by the same letter are not significantly different at 5\% DMRT. (-) : no interaction

\section{The ratio of the root/crown}

Comparison of root growth and tip growth (canopy) is usually expressed as the ratio of roots/crown that has physiological importance as it illustrates one type of drought tolerance mechanism. Analysis of variance showed that shading and watering frequency caused no significant effect on the ratio of the root/crown. This is, presumably, because the influence of genetic factors on root/crown ratio was greater than that of environmental factors (Gardner et al. 1991).

\section{Weight of simplicia}

Simplicia is the parts of plants that have been dried and used as ingredients in pharmaceutical manufacturing. Parts of $R$. serpentina plants commonly used for medicine are the roots. Our analysis of variance revealed no significant effect of shading and watering frequency treatments on the weight of simplicia. The weight of simplicia is affected by root length and root diameter. In the present study, we found that the plant root was not significantly affected by shading and watering frequency treatments so that the weight of the simplicia was also not significantly affected by the treatments.

\section{Reserpine content}

The main purpose of cultivation of medicinal plants is to obtain maximum biomass containing the highest secondary metabolites. A secondary metabolite is a compound produced by plants to sustain their life and is mostly a defense mechanism for plants to cope with attacks from outside, such as viruses and bacteria (Rogerio et al. 2010).

Sulandjari (2008) stated that both the climate and the sun affected the photosynthesis process in relation to primary and secondary metabolite formation. Figure 2 shows that the highest levels of reserpine were found at $65 \%$ shading level treatment with the watering frequency of five-day intervals, while the lowest was at $75 \%$ shading treatment with the watering frequency of three and five-day intervals. Figure 2 also shows that at $75 \%$ shading level, the reserpine levels started to decline. This is apparently because, at $75 \%$ shading, the plant metabolism was obstructed so that the reserpine content generated was the lowest. $R$. serpentina is a $\mathrm{C}_{3}$ plant, so the saturation level of light intensity is low. However, the very low-light intensity can decrease photosynthetic activity, which then reduces the secondary metabolites production. Presumably, the light intensity of less than $25 \%$ has inhibited the $R$. serpentina growth, so that its reserpine level was the lowest.
Table 6. Means of root diameter at various levels of shade and watering frequency.

\begin{tabular}{lcccc}
\hline $\begin{array}{c}\text { Level of } \\
\text { shading (\%) }\end{array}$ & \multicolumn{3}{c}{ Watering frequency (days) } & Means \\
\cline { 2 - 4 }$(\mathbf{c m})$ \\
\hline 55 & $\mathbf{3}$ & $\mathbf{5}$ & $\mathbf{7}$ & \\
65 & 0.72 & 0.84 & 0.58 & $0.71 \mathrm{a}$ \\
75 & 0.61 & 0.76 & 0.50 & $0.62 \mathrm{a}$ \\
Means $(\mathrm{cm})$ & 0.60 & 0.61 & 0.56 & $0.59 \mathrm{a}$ \\
\hline
\end{tabular}

Note: Means on the same column or same line followed by the same letter are not significantly different at 5\% DMRT. (-) : no interaction

Table 7. The means of the ratio of the root/crown at various levels of shade and watering frequency

\begin{tabular}{lllll}
\hline \multirow{2}{*}{$\begin{array}{c}\text { Level of } \\
\text { shading (\%) }\end{array}$} & \multicolumn{3}{c}{ Watering Frequency (days) } & \multirow{2}{*}{ Means } \\
\cline { 2 - 4 } & $\mathbf{3}$ & $\mathbf{5}$ & $\mathbf{7}$ & \\
\hline 55 & 0.57 & 0.31 & 0.23 & $0.37 \mathrm{a}$ \\
65 & 0.54 & 0.50 & 0.31 & $0.42 \mathrm{a}$ \\
75 & 0.89 & 0.89 & 0.72 & $0.83 \mathrm{a}$ \\
Means & $0.67 \mathrm{c}$ & $0.57 \mathrm{c}$ & $0.42 \mathrm{c}$ & $(-)$ \\
\hline
\end{tabular}

Note: Means on the same column or same line followed by the same letter are not significantly different at 5\% DMRT. (-) : no interaction

Table 8. The means of the weight of simplicia at various levels of shade and watering frequency

\begin{tabular}{lcccc}
\hline \multirow{2}{*}{\begin{tabular}{l} 
Level of shading \\
\cline { 2 - 4 }
\end{tabular}} & \multicolumn{3}{c}{ Watering frequency (days) } & Means \\
\cline { 2 - 4 }$(\mathbf{3})$ & $\mathbf{3}$ & $\mathbf{5}$ & $\mathbf{7}$ & $(\mathrm{g})$ \\
\hline 55 & 5.703 & 4.714 & $4.61 \mathrm{a}$ \\
65 & 2.877 & 4.765 & 2.024 & $3.22 \mathrm{a}$ \\
75 & 1.852 & 1.978 & 2.714 & $2.18 \mathrm{a}$ \\
Means (g) & $3.48 \mathrm{c}$ & $3.05 \mathrm{c}$ & $3.48 \mathrm{c}$ & $(-)$ \\
\hline
\end{tabular}

Note: Means on the same column or same line followed by the same letter are not significantly different at 5\% DMRT. (-) : no interaction

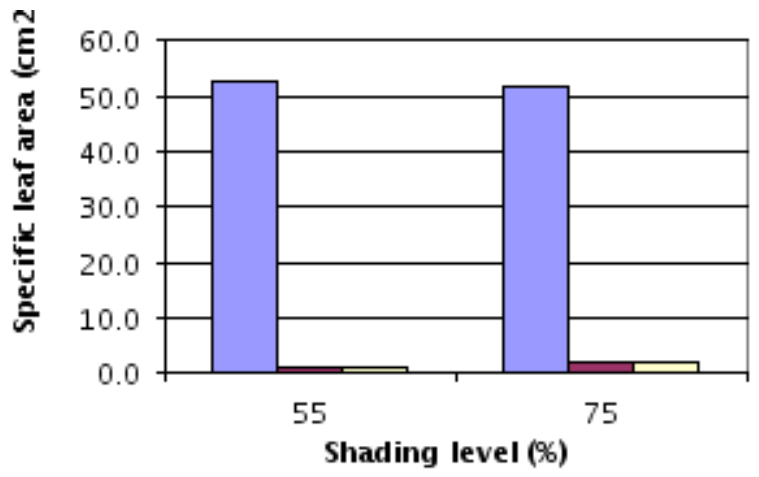

Figure 1. Specific leaf area of Rauvolfia serpentina at various levels of shading 


\section{:

0

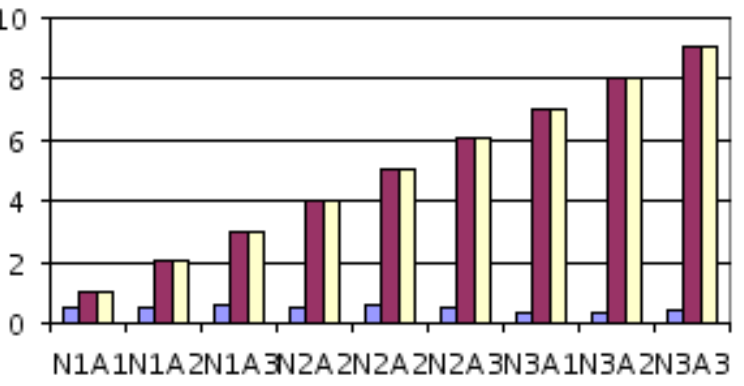

Treatments

Figure 2. Reserpine content of Rauvolfia serpentina at various treatments of shading level and watering frequency

In conclusion, there was no significant interaction effect of shading level and watering frequency on all the observed variables. The shading level treatment did not affect the growth and yield of $R$. serpentina, except on leaf area that was the narrowest at the $75 \%$ shading level. Different watering frequencies caused significant influence on growth and yield of $R$. serpentina, except for the chlorophyll content that increased in the watering frequency every five days. The highest reserpine content was found in $65 \%$ shading level treatment with the watering frequency of five-day intervals.

\section{REFERENCES}

Fosked DE. 1994. Plant Growth and Development. A Molecular Approach.Academic Press. New York.

Gardner FP, Pearce RB, Mitchell RI. 1991. Physiology of Crop Plants. Translation: Fisiologi Tanaman Budidaya. Translator: H. Susilo. Facilitators: Subiyanto. UI Press, Jakarta. [Indonesian]

Guritno B, Purnomo D. 2006. The response of soybean variety on low irradiation. J Agrosains 8 (1):21-26. [Indoensian]

Herlina N. 1996. The response of soybean of Malabar variety and s$887 / 96$ stains against drought stress and potassium fertilization. J Agrivita 19 (2): 63-64. [Indonesian]

Hidayat, E.B. 1995. Anatomy of Seed Plants. ITB, Bandung. [Indonesian]

Islami T, Utomo WH. 1995. Relations of Land, Water, and Plants. IKIP Semarang Press, Semarang. [Indonesian]

Lakitan B. 1993. Basics of Plant Physiology. PT. Raja Grafindo Persada, Jakarta. [Indonesian]

Misra N, Misra R. 2012. Salicylic acid changes plant growth parameters and proline metabolism in Rauwolfia serpentina leaves grown under salinity stress. Amer-Eur J Agric Environ Sci 12: 1601-1609.

Rogerio AP1, Sá-Nunes A, Faccioli LH. 2010. The activity of medicinal plants and secondary metabolites on eosinophilic inflammation. Pharmacol Res 62 (4): 298-307.

Sitompul SM, Guritno B. 1995. Plant Growth Analysis. Gadjah Mada University Press, Yogyakarta. [Indonesian]

Streitweiser A, Heathcock CH. 1981. Introduction to Organic Chemistry. Macmillan, New York.

Sulandjari, Pramono S, Wisnubroto S, Indradewa D. 2005. Microclimate relationships with growth and yield of pule pandak (Rauvolfia serpentina Benth). J Agrosains 7 (2): 71-76. [Indonesian]

Sulandjari. 2008. Medicinal Plants - Rauvolfia serpentina - Ecophysiology and Cultivation. UNS Press, Surakarta. [Indonesian] 